RAZGLEDI

\title{
PREPOZNAVANJE IN PROSTORSKA RAZMESTITEV KONFLIKTOV NA PODEŽELJU
}

\author{
AVTORICI \\ Špela Guštin \\ Rakovčeva ulica 2, SI - 6330 Piran, Slovenija; spela.gustin@gmail.com \\ dr. Irma Potočnik Slavič \\ Univerza v Ljubljani, Filozofska fakulteta, Oddelek za geografijo, Aškerčeva 2, SI - 1000 Ljubljana, Slovenija \\ irma.potocnik@ff.uni-lj.si
}

DOI: $10.3986 / G V 87105$

UDK: 911.3:711.3(497.472)

COBISS: 1.01

\section{IZVLEČEK}

\section{Prepoznavanje in prostorska razmestitev konfliktov na podeželju}

Privlačno večfunkcijsko slovensko podeželje je hkrati tudi stičišče interesov različnih akterjev (kmetje, podjetniki, lastniki sekundarnih bivališč, okoljevarstveniki, obiskovalci, lokalna samouprava, investitorji). Medsebojna prepletenost interesov socialnih skupin in njihovih raznovrstnih zahtev oziroma pričakovanj glede rabe podeželskih virov pogosto vodi v konfliktne situacije, ki zahtevajo celostno geografsko obravnavo. Prispevek se osredotoča na prepoznavanje in prostorsko razmestitev konfliktov na podeželju Občine Izola, njihovo časovno razsežnost in vzročno-posledično povezanost na podlagi večletne analize regionalnega časopisa (2008-2014). Poznavanje interesov in konfliktov, ki nastajajo med akterji oziroma socialnimi skupinami, pomaga pri odločanju o prihodnjem razvoju in trajnostni rabi podeželskih virov.

\section{KLJUČNE BESEDE}

geografija podeželja, večfunkcijsko podeželje, konflikti interesov, analiza vsebine časopisa, kmetijstvo, turizem, zavarovana območja, prostorsko planiranje, Občina Izola

\section{ABSTRACT}

\section{Identification and spatial distribution of conflicts in rural areas}

Attractive and multifunctional Slovenian rural areas often perform as a junction of various stakeholders (farmers, entrepreneurs, second home owners, environmentalists, tourists, local authorities, investors, etc.) and their interests. Interrelations among interests of social groups and their diverse requests or expectations towards the use of rural resources very often lead into conflict situations which ask for holistic geographical analysis. The paper focuses on identification and spatial distribution of conflicts in rural areas of the Municipality of Izola (Slovenia), their spatial dimension, cause-effect connection on the basis of regional newspaper content analysis (2008-2014). Knowledge on interests and conflicts among stakeholders or social groups contributes to decision-making process on future development and sustainable use of rural resources.

\section{KEY WORDS}

rural geography, multifunctional rural areas, conflicts of interests, newspaper content analysis, agriculture, tourism, protected areas, spatial planning, Municipality of Izola

Uredništvo je prispevek prejelo 29. maja 2015. 


\section{Uvod}

Slovensko podeželje ima izrazito večfunkcijski značaj (Klemenčič, Lampič in Potočnik Slavič 2008; Program razvoja podeželja 2014-2020). V informacijski dobi se gospodarski pomen kmetijstva zmanjšuje, vedno večji gospodarski pomen in vlogo pri odločanju o razvoju podeželja pa imajo storitvene dejavnosti (na primer turizem, rekreacija, trgovina) in načelna usmeritev države v trajnostni razvoj, ki jo je moč razbrati prek akterjev, povezanih z varstvom narave oziroma kulturne dediščine. Vse navedene in še druge funkcije (na primer prometna, varstvena, zdravstvena, estetska, politična) se med sabo vzročno-posledično prepletajo: kmetijsko zemljišče je lahko hkrati namenjeno pridelavi hrane in ohranjanju kulturne pokrajine, prav zaradi tega pa je lahko privlačno tudi za pozidavo in izgradnjo turistične (na primer pohodniške) infrastrukture. Na območjih in področjih, kjer si interesi (raznovrstnih) akterjev glede rabe podeželskih virov (pokrajina, rastje in živalstvo, biotska raznovrstnost, podeželska naselja, prometne poti, geologija, kakovost zraka in vode, gozdovi, lokalne navade, jedi, prireditve in jezik; Garrod, Wornell in Youell 2006) nasprotujejo, nastanejo konflikti interesov. Na teh območjih in področjih pogosto prihaja do velikih sprememb, ker nasprotujoči si interesi tekmujejo za različne vrste rabe tal, močno preoblikujejo nekatere dele pokrajine in hkrati varujejo druge (The future ... 1988).

O konfliktih interesov na podeželju lahko v tuji literaturi najdemo dosti prispevkov (Woods 1998; 2003a; 2003b; 2005; 2006), v domači pa so večinoma le omenjeni, na primer konflikti med domačini in lastniki počitniških hiš na podeželju (Goluža 2014, 45-46), konflikti med kmečkimi in nekmečkimi prebivalci (Perpar 2002, 134 v: Perpar, Kovačič 2006, 67), konflikt kmetijstva in rabe naravnih virov (Lampič 2008), konflikti glede prostorske rabe (Potočnik Slavič 2010), konflikti med kmetijskimi pritiski in okoljem ter med poselitvijo in naravnimi viri (Klemenčič, Lampič in Potočnik Slavič 2008) ali pa je predmet raziskave predstavitev postopka za usklajevanje različnih interesov in preprečevanje konfliktov (Golobič, Marušič in Kovačič 2003).

Pregleda prostorske razporeditve konfliktov ali analize spreminjanja števila oziroma intenzivnosti konfliktov v daljšem časovnem obdobju pa v razpoložljivi literaturi nismo zasledili. Tovrstni podatki se tudi ne vodijo v evidenci, čeprav so takšne situacije v pokrajini zelo žive. Namen prispevka je v pokrajini prepoznati, prikazati in analizirati prostorsko razporeditev ter spreminjanje števila in intenzivnosti konfliktov na podeželju Občine Izola v obdobju 2008-2014.

\section{Opredelitev problema}

Konflikt je v Slovarju slovenskega knjižnega jezika (2014) opredeljen kot »duševno stanje nemoči zaradi nasprotujočih si teženj«, enotne opredelitve pa v literaturi ni. Lahko pomeni vse od manjšega spora med dvema osebama pa do svetovne vojne (The dictionary ... 2009). Večinoma konflikte dojemamo kot nekaj slabega, negativnega. Sociolog Dahrendorf $(1959,208)$ jih je opredelil kot dobre in zaželene ter kot povod za ustvarjalnost, inovacije in razvoj posameznika ter družbe.

Iz pregleda literature lahko opredelitve konflikta glede na prevladujoč vzrok za nastanek razdelimo v dve skupini:

- nezdružljivi interesi oziroma nasprotujoče lastnosti akterjev (Boulding 1962, 5 v: Janelle in Milward 1976; Coser 1964 v: Mann in Jeanneaux 2009; Pavón in sodelavci 2003; Wehrmann 2008; von der Dunk in sodelavci 2011),

- želja po dobrini, katere količina je omejena (Jones in sodelavci 2005; Grimble in Wellard 1997).

Na podlagi tega bi konflikt kot ga razumemo v okvirih pričujočega prispevka lahko opredelili kot nasprotje med akterji, ki nastane zaradi nezdružljivih interesov po omejeni dobrini.

V različnih geografskih raziskavah konflikte različno prikazujemo. Tako lahko v politični geografiji zasledimo Cohenovo idejo političnega zemljevida sveta, razdeljeno na geopolitična območja, ki se prekrivajo. Na teh vmesnih območjih prekrivanja so konflikti stalno prisotni (Bufon 2007, 42-43). Konf- 
likti so torej vezani na lokacijo. Pri konfliktih, povezanih s spremembami rabe tal, je prav lokacija pogosto tisti odločilni dejavnik nestrinjanja (Janelle 1979). Na vmesnem območju med mestom in podeželjem so konflikti zelo raznovrstni: zvočno in vizualno onesnaževanje, varstvo naravne in kulturne dediščine, zdravju nevarne dejavnosti in spremembe v bližnji okolici (von der Dunk in sodelavci 2011), zasledimo pa lahko tudi konflikte glede umeščanja neželenih vrst rabe tal (Bennett in Davies 2015) in konflikte kmetijstva z drugimi dejavnostmi (Henderson 2005; Darly in Torre 2013). Konflikte na podeželju je Woods $(2005,211)$ razdelil v tri skupine: (1) konflikt med potrebo po razvoju podeželja in okoljskimi vplivi, (2) konflikt med kmetijskimi in varstvenimi interesi glede rabe naravnih virov in (3) konflikt med podeželskim načinom življenja in omejevanjem lova na divje živali.

$\mathrm{Na}$ podeželju je več akterjev z različnimi željami glede rabe prostora (slika 1). Kot pomembnejše akterje na podeželju Občine Izola izpostavljamo kmete, ki so tudi najštevilčnejši, lastnike počitniških bivališč, naravo- oziroma kulturovarstvenike ter prostorske načrtovalce.

Najprimernejša območja za kmetijstvo v Občini Izola so ravnine in prisojna pobočja (Gosar in sodelavci 1976, 19). Ravninski predeli z najboljšimi kmetijskimi zemljišči so podvrženi velikemu navzkrižju interesov različnih sektorjev (Cimprič, Lisec in Zavodnik Lamovšek 2013, 575). Zaradi vedno večjega števila nekmečkih prebivalcev, ki ne razumejo potrebe po zemljiščih, primernih za pridelavo hrane, so še posebno problematične kratkovidne zahteve po spremembah kmetijkkih zemljišč v druge rabe (Gosar in sodelavci 1976, 11). Med letoma 1955 in 1975 se je površina njiv in vrtov v občinah Koper, Izola in Piran zmanjševala za 60 ha na leto, povečevala pa površina gozdov za 220 ha na leto. Ob enakem spreminjanju strukture površin so avtorji kmetijskega prostorskega načrta za obalne občine leta 1976 predpostavili, da čez 45 let (leta 2021) v teh treh občinah ne bo več kategorije »kmetijske površine« (Gosar in sodelavci 1976, 11). Obseg kmetijskih zemljišč v Sloveniji se še vedno zmanjšuje na račun urbanizacije in zaraščanja kmetijskih zemljišč (Vrščaj 2011). Zakon o kmetijskih zemljiščih (2011) določa, da se ob spremembi namembnosti kmetijskih zemljišč plačuje odškodnina, ni pa še jasno, ali ta ukrep dosega svoj namen in preprečuje nepremišljene spremembe kmetijskih zemljišč v pozidana (Cimprič, Lisec in Zavodnik Lamovšek 2013).

Zavarovana območja (narodni, regijski in krajinski parki, naravni rezervati, naravni spomeniki, območja Natura 2000) so dragocena, vredna območja, ki so bila zavarovana zaradi svoje izjemnosti, v nekaterih primerih tudi zaradi ogroženosti. Imajo številne, pogosto slabo prepoznane potenciale. Med prebivalci in obiskovalci zavarovanih območij v Sloveniji je še najbolj prepoznan okoljski potencial mirno in čisto okolje, ohranjena naravna pokrajina ter biotska raznovrstnost (Lampič in Mrak 2008).

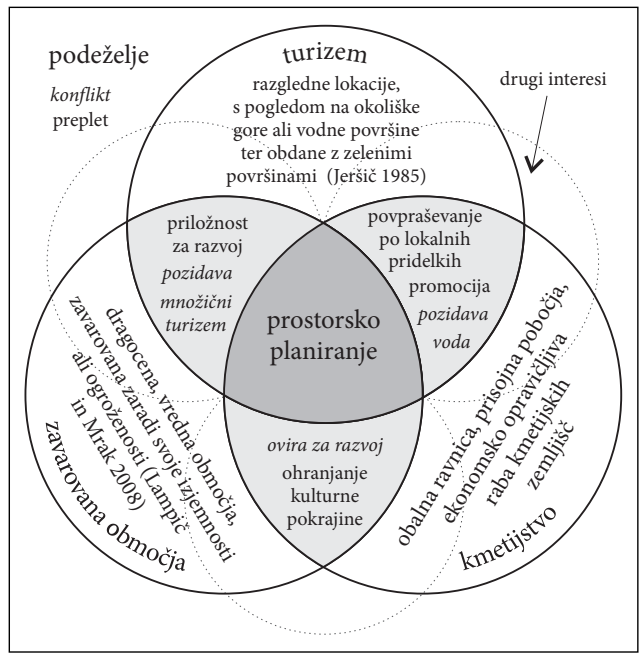

Slika 1: Podeželje kot poligon raznovrstnih interesov. Kjer se območja različnih interesov prekrivajo, prihaja do konfliktov, a tudi do obojestranske koristi. Usklajevanje vseh interesov je naloga prostorskega planiranja. 
Družba ima obvezo varovati taka območja za sedanje in prihodnje generacije (Dixon in Sherman 1991), a se običajno dojemajo kot omejitev in ne kot priložnost (Simoneti in Vertelj Nared 2011; Lampič in Mrak 2008).

Privlačnost območja za turizem je odvisna od lokacije in od posebnosti, ki so lastne tej lokaciji. Med posebnosti lahko uvrščamo različne naravne vrednote (na primer obale morja, jezer ali rek), podnebje (število dni s soncem, temperatura), kulturno okolje (izobraževalne ustanove, kulturne znamenitosti), družbeno infrastrukturo (stopnja kriminala, kakovost javnih storitev), kakovost grajenega okolja (zraka, vode, infrastrukture) (Power 2005, 65). Območje je privlačno, ko se na njem prepleta več takih posebnosti, ne le ena (Jeršič 1986,60$)$.

Zaradi prepleta funkcij je turizem na zavarovanih območjih običajno prepoznan kot najprimernejša dejavnost in priložnost za razvoj območja (Haukeland, Daugstad in Vistad 2011). Podeželje ima velike zaloge podeželskega kapitala (pokrajina, rastje in živalstvo, biotska raznovrstnost, podeželska naselja, poti, geologija, kakovost zraka in vode, gozdovi, lokalne navade, jedi, prireditve in jezik; Garrod, Wornell in Youell 2006), ki je podlaga za razvoj turizma na podeželju in ga pomagajo ohranjati tudi zavarovana območja. Čeprav se na takih območjih turisti zdijo moteč element, se jim prebivalci ne želijo v celoti odpovedati, saj prinašajo velik del dohodka (Barbič 2005, 100). Zavarovana območja pa so zaradi svoje izjemnosti tudi privlačna za gradnjo počitniških bivališč, ki se običajno razlikujejo od drugih zgradb po obliki, velikosti ali izpostavljeni legi izven obstoječih naselij (Jeršič 1986, 65). Že leta 1986 je Jeršič ugotavljal, da bi v primeru, če bi gradnja počitniških hiš postala množičen pojav, zajela velike površine privlačnih območij. Množičen obisk je tudi ena izmed prepoznanih možnosti za konflikte na zavarovanih območjih (European heritage heads forum 2010).

Tudi povezava kmetijstva in turizma je lahko razvojna priložnost (Klemenčič, Lampič in Potočnik Slavič 2008). Z obdelovanjem kmetijskih zemljišč kmetje ohranjajo kulturno pokrajino, ki je zato bolj privlačna za turistični obisk (Vanslembrouck in van Huylenbroeck 2005; Clendenning in Field 2005).Večji obisk lahko poveča povpraševanje po lokalnih kmetijskih pridelkih, promocija turizma in kmetijstva pa se dopolnjujeta (Bowen, Cox in Fox 1991). A povečano zanimanje lahko privede tudi do želje po pozidavi. Zaradi lege na izpostavljenih lokacijah izven obstoječih naselij (Jeršič 1986) je gradnja počitniških bivališč pogost predmet konflikta med kmetijstvom in turizmom. Konflikt pa lahko povzročijo tudi dejavnosti, ki porabijo veliko vode (na primer igrišče za golf), saj sta tako turizem kot kmetijstvo njena velika porabnika (Bowen, Cox in Fox 1991).

Med interesi kmetijstva in zavarovanih območij lahko nastanejo konflikti zaradi intenzifikacije kmetijstva in zmanjševanja biotske raznovrstnosti (Shackelford in sodelavci 2015), oziroma zaradi omejitev, ob katere trči kmetijstvo, saj prebivalcem režimi in namen varovanja pogosto niti niso poznani (Lampič in Mrak 2008). Obojestransko korist pa prinaša obdelovanje kmetijskih zemljišč, saj s tem kmetje ohranjajo kulturno pokrajino (Daugstad, Rønningen in Skar 2006).

Interese vseh akterjev je treba usklajevati, saj njihovo sektorsko obravnavanje vodi v konflikte (Golobič, Marušič in Kovačič 2003). To je naloga prostorskega načrtovanja (Zakon o prostorskem ... 2007, 3. člen), dolžnost predstavnikov vseh interesov v prostoru pa, da so njihovi interesi usklajeni tako, da pri kasnejši uporabi prostorskega akta ne dopuščajo dvoma (Mlakar 2009). A pri preučevanju podeželja ugotovimo, da tam praviloma veljajo prostorski ureditveni pogoji z ohlapnimi merili za oblikovanje in umeščanje objektov v prostor (Stanič in sodelavci 2000, 18), da se kmetijski pridelovalni prostor obravnava kot prazen prostor za gradbene posege, kmetijstvo pa kot dejavnost, ki se v njem odvija začasno in jo je mogoče kadarkoli odstraniti (Perpar in Kovačič 2006, 62).

\section{Metodologija}

Analiza vsebine je kvantitativna metoda za povzemanje in analiziranje sporočil (Neuendorf 2002, 10). S štetjem pojavljanja predhodno določenih spremenljivk (besed) v sporočilih dobimo številčni povze- 
tek pregledanih sporočil (Neuendorf 2002), ki nam lahko pokaže vzorce pojavljanja različnih dogodkov v času (Barranco in Wisler 1999). Uporablja se zlasti v družboslovju za analizo poročanja medijev o raznovrstnih temah: na primer o kriminaliteti (Bučar Ručman 2011) ali medijski podobi dela geodetov (Erjavec in Poler Kovačič 2011). Metoda se pogosto uporablja tudi pri proučevanju konfliktov (Janelle in Millward 1976; Janelle 1977; 1979; von der Dunk in sodelavci 2011; Darly in Torre 2013; Pelletier in sodelavci 2011).

Zbiranje oziroma pregled časopisov za daljše časovno obdobje je časovno zelo zahtevno, zato se pogosto poslužujemo vzorčenja. V takih primerih lahko zberemo manjše število dogodkov, kot jih je bilo v resnici (Earl in sodelavci 2004). Časopisi različno poročajo o dogodkih, kar je na primer razvidno iz primerjave poročanja o kriminaliteti v časnikih Delo in Slovenske novice (Bučar Ručman 2011) ali iz primerjave poročanja o protestih $\mathrm{v}$ Švici (von der Dunk in sodelavci 2011). Na poročanje vplivata tudi oddaljenost in število udeležencev: dlje, kot je dogodek od sedeža uredništva, manj verjetno je, da bo časopis poročal o njem, hkrati pa je večja verjetnost poročanja o dogodkih z več udeleženci (Barranco in Wisler 1999). Prednost uporabljene metode je objektivnost (Kodeks ... 2015), pomislek pa predvsem, ali en časopis zadostuje, da zberemo podatke za vse dogodke, ki so se zgodili na nekem območju. Če preučevano območje ne obsega celotne države, lahko pričakujemo, da časopisi, ki pokrivajo celotno državo, o dogodkih na tem območju ne bodo poročali enako temeljito kot lokalni časopisi. Branje dveh časopisov, nacionalnega in lokalnega, pa ne prinese bistveno boljše bere podatkov (Barranco in Wisler 1999). Pristranskost časopisov se kaže tudi v ne-poročanju: kjer ni novinarjev, tudi ni novic (Barranco in Wisler 1999), pomanjkanje novic o določeni temi pa je lahko tudi pomemben podatek (Janelle 1977).

O konfliktih interesov se ne vodi uradna evidenca ali druga zbirka podatkov, zato smo podatke pridobili $\mathrm{z}$ analizo vsebine časnika Primorske novice. Primorske novice izhajajo vse dni v tednu, razen ob nedeljah in praznikih. Pregledali smo vse številke v letih 2008, 2009, 2010, 2011, 2012, 2013 in 2014. Na podlagi navedb v literaturi (Janelle 1979; von der Dunk in sodelavci 2011) so že tri leta dovolj dolgo obdobje, da se pokažejo vse vrste konfliktov na nekem območju. Dokaj kratko obdobje je tudi posledica dejstva, da število člankov pri pregledu za več preteklih let hitro postane neobvladljivo. Ker smo se omejili le na stalno rubriko »Istra" in so članki bili v elektronski obliki (v pdf zapisu smo jih pridobili na časopisno založniški družbi Primorske novice v Kopru), smo lahko pregledali članke za daljše časovno obdobje. S tem smo poskušali odpraviti težavo nihanja števila objavljenih člankov v posameznem letu in hkrati upoštevati dejstvo, da so spremembe prostorskih aktov dlje trajajoči postopki (slika 2), kar vpliva tudi na pojavljanje konfliktov. V časopisu smo iskali članke po ključu, ki je bil uporabljen za iskanje konfliktov rabe tal $v$ mestu (Janelle 1977). Iskali smo: (a) članke s konflikti interesov na podeželju Občine Izola, (b) članke, kjer je bilo očitno nestrinjanje med dvema ali več akterji in (c) članke, ki so imeli opredeljeno lokacijo (točko, linijo ali območje) oziroma smo lokacijo lahko razbrali iz fotografije v članku.

Pri vsakem članku, ki je ustrezal zgornjim pogojem, smo v preglednico izpisali podatke o datumu objave, lokacijo konflikta (parcelno ali hišno številko), predlagatelja spremembe, razlog konflikta in število znakov brez presledkov v članku. Evidentirali smo tudi število člankov o istem konfliktu. Če je bilo v enem članku omenjenih več konfliktov, smo ta članek šteli večkrat - po enkrat za vsak konflikt. Intenzivnost konflikta smo merili s štetjem števila znakov brez presledkov v članku. Običajno se namesto števila znakov uporablja dolžina članka v centimetrih (oziroma inčih; Janelle in Millward 1976) ali površina članka v kvadratnih centimetrih (oziroma inčih; Janelle 1977), a je bilo štetje znakov enostavneje kot merjenje dolžine ali površine. $\mathrm{V}$ številu znakov ni bilo zajeto ime in priimek avtorja članka ter ime in priimek avtorja morebitnih fotografij. Zaradi štetja znakov v merilu intenzivnosti niso upoštevane fotografije, ki so pogosto del članka in bi jih zajeli, če bi merili dolžino ali površino članka. Lokacije konfliktov smo georeferencirali kot točke v programu ArcMap 10.1. Pomagali smo si s slojema hišnih številk in parcel, ki smo ju pridobili na Geodetski upravi Republike Slovenije. Če se je konflikt nanašal na območje, smo mu določili centroid. $V$ atributno tabelo sloja pa smo prepisali podatke iz preglednice, ki smo jo izpolnjevali ob pregledovanju člankov. 


\section{Rezultati}

V rubriki »Istra« v časniku Primorske novice je bilo v sedemletnem obdobju 2008-2014 napisanih 87 člankov o konfliktih na podeželju Občine Izola, v katerih je bilo omenjenih 21 konfliktov. Štiri članke smo upoštevali dvakrat, ker sta v vsakem od njih bila omenjena po dva konflikta. Dvema od 21 konfliktov (oznaki 14 in 21 na sliki 3e) nismo mogli določiti lokacije, ker se je eden nanašal na celotno območje Prostorskih ureditvenih pogojev za podeželje Občine Izola, drugi pa je bil podan le z lokacijo katastrske občine. Vseeno smo ju upoštevali, a zarisali izven meje Občine Izola. Konflikti so se med sabo razlikovali po lokaciji, intenzivnosti (številu objav in številu znakov brez presledkov), predlagatelju spremembe (investitor, kmet, občina, Družba za avtoceste v Republiki Sloveniji (DARS), več predlagateljev), vzroku za nastanek (nelegalna gradnja, gradnja infrastrukture, načrtovanje umestitve nove dejavnosti/objekta, sprememba prostorskega akta) in trajanju (enkraten, večleten, ponavljajoč).

\subsection{Nihanje števila in intenzivnosti konfliktov}

Število člankov o konfliktih in število zabeleženih konfliktov je nihalo po letih. Največ konfliktov je bilo zabeleženih v letu 2008, najmanj pa v letu 2010. Na leto sta se pojavila v povprečju dva nova konflikta (preglednica 1). Časovni potek ključnih dogodkov, povezanih s konflikti na podeželju Občine Izola, je prikazan na sliki 2.

Preglednica 1: Število člankov, zabeleženih konfliktov in konfliktov, ki se v izbranem letu pojavijo prvič.

\begin{tabular}{lccc}
\hline leto & število člankov o konfliktih & število konfliktov & število konfliktov, ki se pojavijo prvič \\
\hline 2008 & 17 & 9 & $-^{\mathrm{d}}$ \\
2009 & 11 & 4 & 1 \\
2010 & 7 & 3 & 1 \\
2011 & 8 & $5^{\mathrm{a}}$ & 3 \\
2012 & $10+3^{\mathrm{c}}$ & 5 & 3 \\
2013 & $22+1^{\mathrm{c}}$ & $7^{\mathrm{b}}$ & 3 \\
2014 & 12 & $6^{\mathrm{b}}$ & 1 \\
vsota & $87+4^{\mathrm{c}}$ & $39^{\mathrm{c}}$ & 12 \\
\hline
\end{tabular}

${ }^{a}$ Vštet konflikt, ki mu ni bilo mogoče določiti lokacije.

${ }^{\mathrm{b}}$ Vštet konflikt, ki se je nanašal na celotno območje Prostorskih ureditvenih pogojev za podeželje Občine Izola in mu ni bilo mogoče določiti lokacije.

${ }^{c}$ Dodatni članki so tisti, ki smo jih šteli dvakrat, ker sta bila v njih omenjena dva konflikta.

${ }^{\check{c}}$ Nekateri konflikti se pojavljajo v več letih, zato je vsota konfliktov večja od števila posameznih konfliktov.

${ }^{\mathrm{d}}$ Časopisa nismo brali pred letom 2008, zato nismo mogli z gotovostjo določiti, kateri konflikti so se prvič pojavili v letu 2008.

Glede na trajanje lahko razdelimo konflikte na enkratne, večletne in ponavljajoče. Enkratni se pojavijo samo v enem letu, večletni se pojavljajo nepretrgoma več let, ponavljajoči pa se pojavijo v več letih, a z vmesnimi prekinitvami. V Občini Izola (slika 3c) prevladujejo enkratni konflikti, ki so zgoščeni predvsem na južnem in jugovzhodnem robu mesta Izola, na območju, ki ima zaradi polkrožne oblike ime »amfiteater «. Ponavljajoč konflikt je en sam (oznaka 1 na sliki 3e), večletnih pa je 5 (oznake 5, 6, 13, $14,18)$. V vseh sedmih letih se je pojavljal le en konflikt, dva sta se pojavljala $v$ dveh zaporednih letih (oznaki 6 in 14), eden pa tri leta zapored (oznaka 18). Konflikt 5 smo, kljub temu da je v letu 2010 prišlo do prekinitve, vseeno šteli med večletne konflikte. Konflikta 6 in 14 sta se začela v letu 2012 oziroma 2013, konflikt 18 pa se je končal v letu 2010.

Slika 2: Časovnica ključnih dogodkov, povezanih s konflikti na podeželju Občine Izola. 


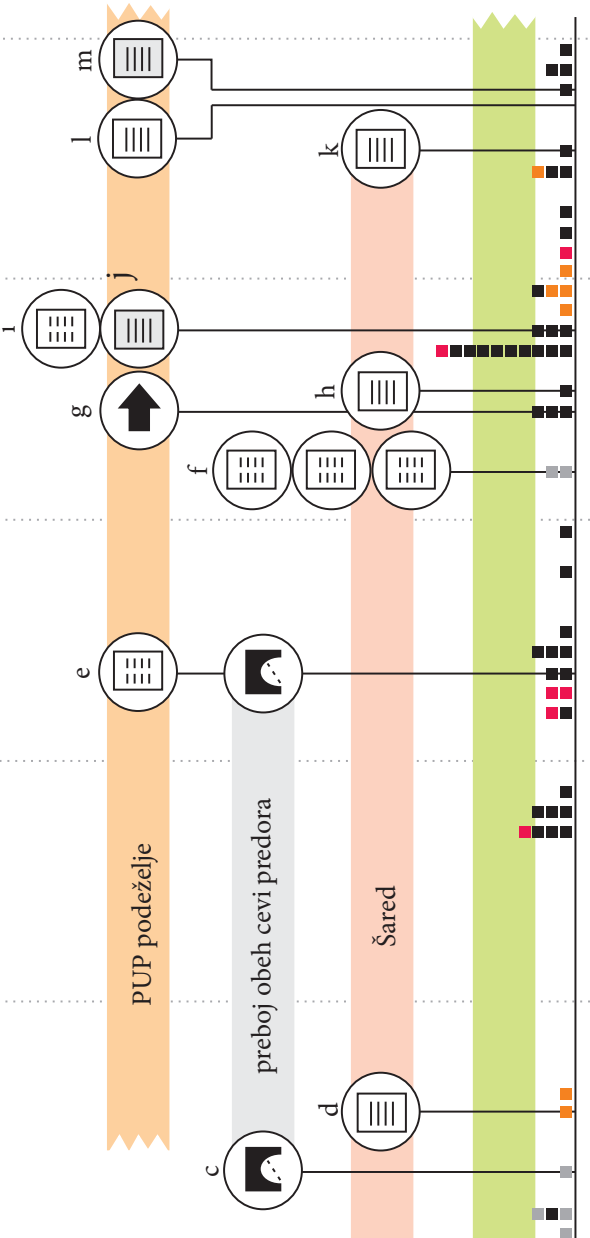

$\stackrel{n}{2}$

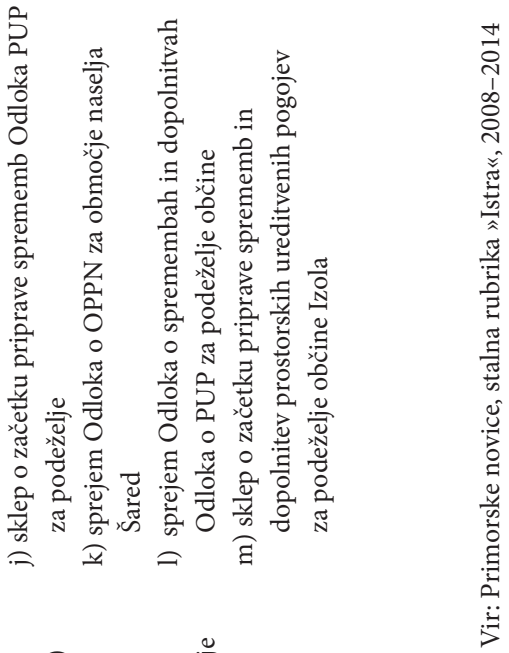

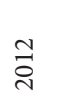

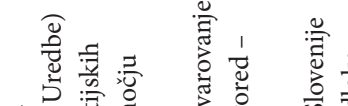
焉 节葡

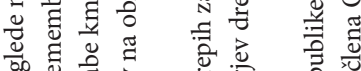
ठै के

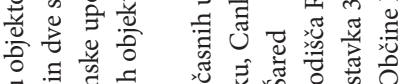

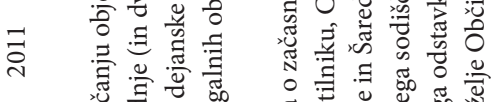


$\mathrm{V}$ vsakem letu se pojavlja različna kombinacija predlagateljev sprememb in vzrokov za nastanek konfliktov (slika 4). Investitorji (med njimi so bili mobilni operater, podjetje za upravljanje z igrišči za golf ter posamezni lastniki nepremičnin iz izolske ali drugih občin) so povzročili konflikte v vseh sed-

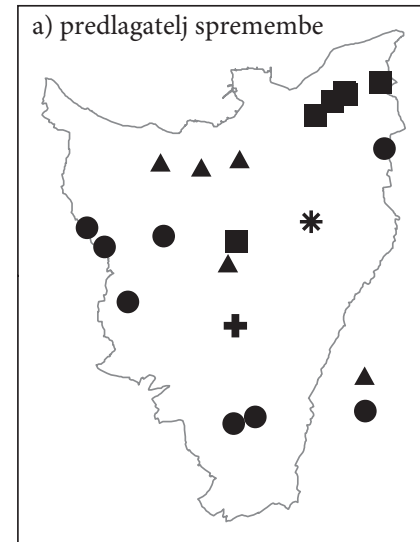

DARS

4 več

investitor

* kmet

$\Delta$ občina

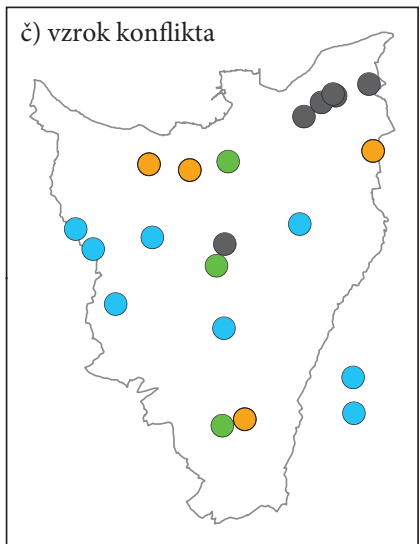

infrastruktura

nelegalna gradnja

nove dejavnosti

sprememba prostorskega akta
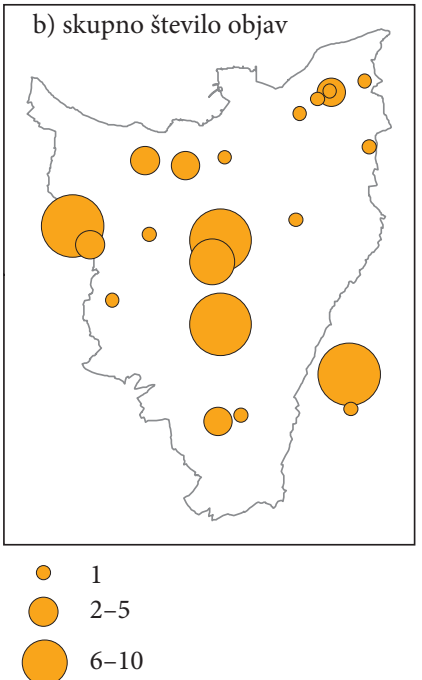

$11-18$
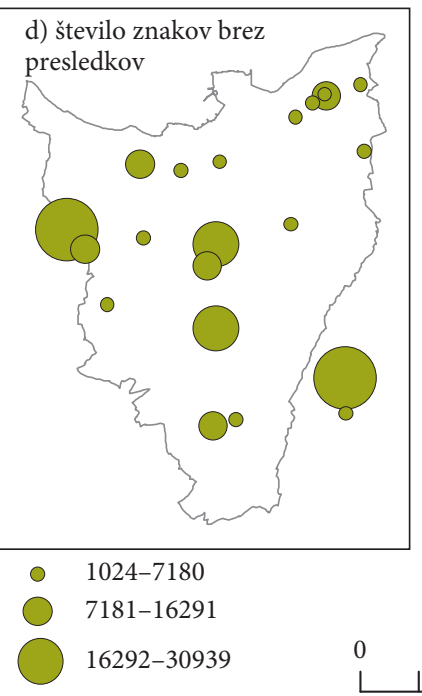

30940-58241

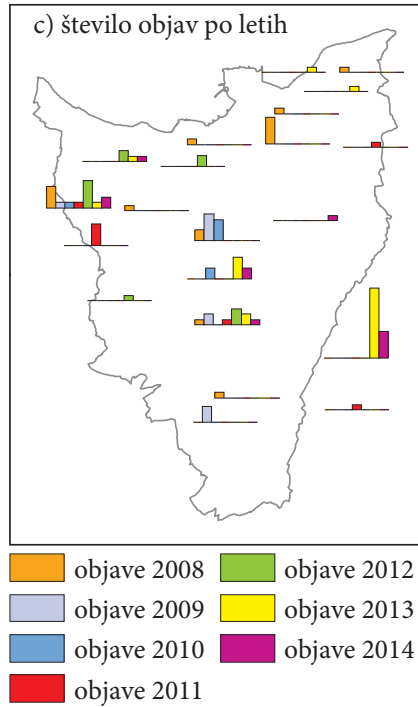

e) ID številke konfliktov
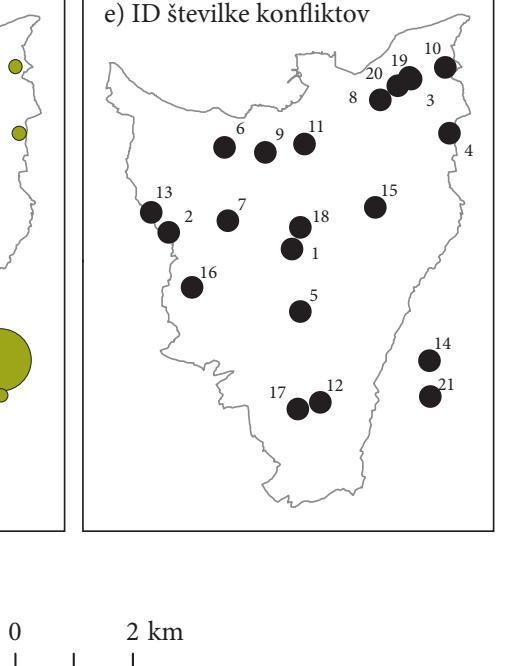

Avtorica vsebine: Špela Guštin

Vir: Primorske novice, stalna rubrika »Istra«, 2008-2014 Podlaga: meja občine (GURS)

Slika 3: Konflikte na podeželju Občine Izola lahko razvrstimo glede na predlagatelja spremembe, število objav, trajanje, vzrok in število znakov. 
mih letih, konflikti zaradi gradnje infrastrukture so bili bolj prisotni med letoma 2008 in 2010, konflikti, v katerih je bila glavni akter Občina, pa v obdobju 2012-2014. Na podlagi slike 4 bi lahko sklepali, da poročanje časopisa ni uravnoteženo. Kadar je bilo objavljenih več člankov o konfliktih zaradi investitorjev (leto 2008), jih je bilo manj o občini in obratno (leto 2014).

Ni namreč vseeno, kdo je predlagatelj spremembe, ki kasneje povzroči konflikt. Konflikte smo razdelili v pet skupin glede na predlagatelja spremembe. Izračunali smo delež konfliktov, ki jih je predstavljala skupina glede na vseh 21 konfliktov in delež uporabljenih znakov za vsako skupino, glede na vseh 276.986 znakov. Deleže smo primerjali med sabo in ugotovili, da so v obdobju 2008-2014 Primorske novice več prostora posvečale konfliktom, ki jih je povzročila občina, v primerjavi s konflikti, kjer so predlagatelji bili drugi akterji (slika 5). O teh konfliktih je bilo napisano več, kot bi pričakovali iz števila konfliktov. Najbolj uravnoteženo je bilo poročanje o konfliktih, ki so jih povzročili investitorji.

Dolgotrajnejši konflikti (sliki 3b in 3d) so praviloma intenzivnejši, saj se o njih pogosteje in več piše. Konflikt pa je lahko intenzivnejši zgolj zato, ker se nanaša na veliko območje in vključuje veliko število

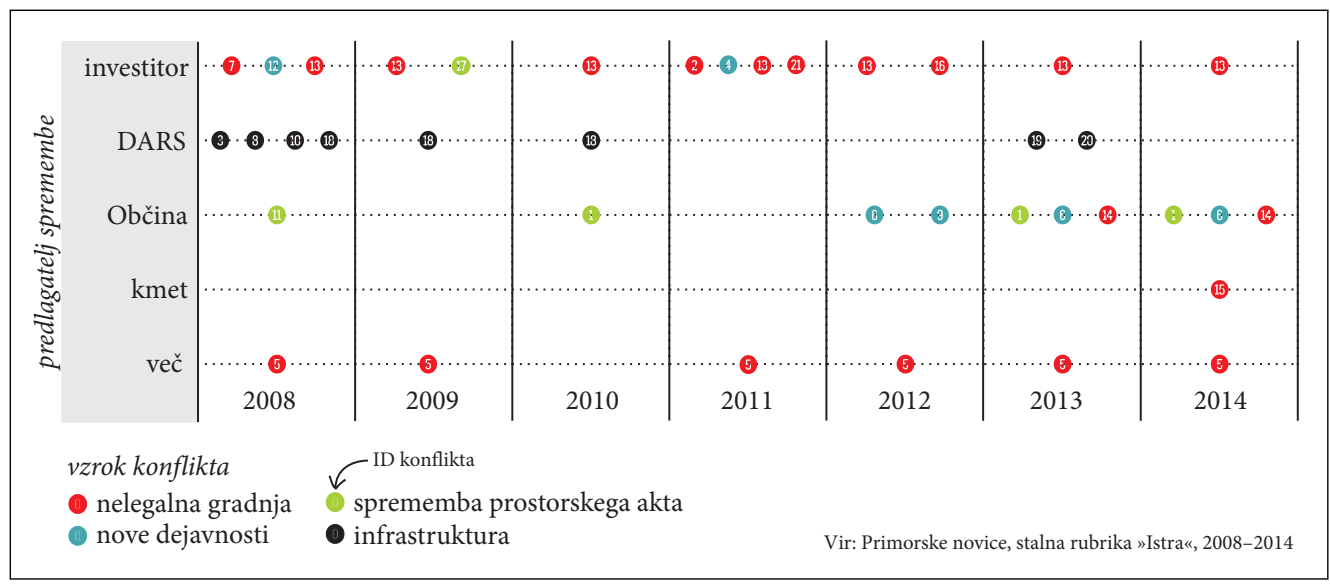

Slika 4: Prisotnost konfliktov po letih, glede na predlagatelja in vzrok.

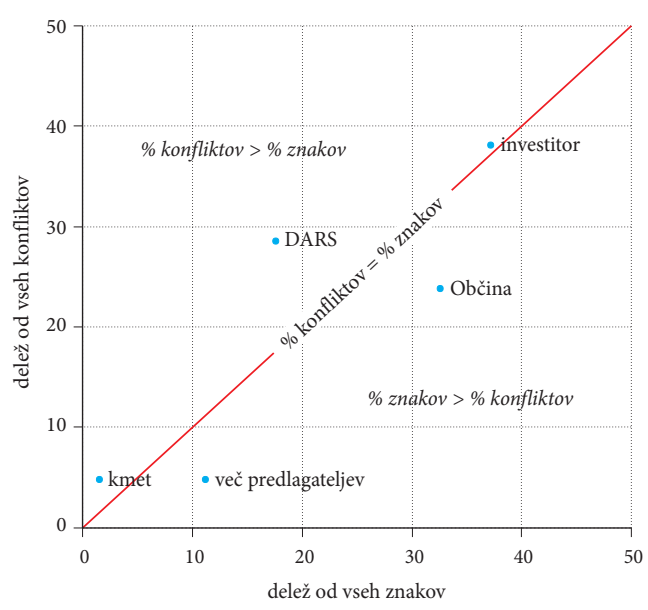

deleži so izračunani glede na 21 konfliktov in 276.986 znakov v člankih
Slika 5: Poročanje časopisa Primorske novice o konfliktih se razlikuje glede na predlagatelja spremembe. 
ljudi. Takšen je primer konflikta 14, ki se je nanašal na celotno območje, ki se ureja z Odlokom o prostorskih ureditvenih pogojih za podeželje v Občini Izola in so vanj bili vključeni vsi, ki jim kmetijska zemljišča daje v zakup Sklad kmetijskih zemljišč in gozdov Republike Slovenije. Čeprav se je o tem konfliktu pisalo le dve leti, je njegova intenzivnost primerljiva s konfliktom 13, ki je bil zabeležen v vseh sedmih letih.

Med povzročitelji in lokacijami konfliktov so zapletene vzročno-posledične povezave, odvisne od več dejavnikov: (prostorskih) projektov, ki so v tistem trenutku aktualni v občini, trenutno veljavne zakonodaje in interesov posameznikov.

\subsection{Vzroki za nastanek konfliktov}

Glede na vzrok lahko razdelimo konflikte v štiri skupine (slika 3č): konflikti zaradi gradnje infrastrukture, zaradi nelegalnih gradenj, zaradi načrtovanja umestitve nove dejavnosti ali objekta ter zaradi spremembe prostorskega akta.

Tretjina vseh konfliktov je povezana z nelegalnimi gradnjami, to je z željo po gradnji na kmetijskih zemljiščih (oznaka 2 na sliki 3e), rušitvijo že zgrajenega objekta (oznake 7, 15 in 21), pregledom obstoječih nelegalnih gradenj (oznaka 14), in stavbami, ki so že zgrajene (oznake 5, 13 in 16). Ti konflikti se pojavljajo v vseh sedmih letih (slika 6). Predlagatelji sprememb pri nelegalnih gradnjah so bili v petih primerih investitorji, od teh je en konflikt nastal še preden je prišlo do neželene spremembe (oznaka 2).Tri nelegalne gradnje se pojavljajo na območju, od koder je vidno morje (slika 7), na tem območju je tudi veliko nelegalnih objektov na kmetijskih zemljiščih (oznaka 14). Konflikt 14 je nastal zaradi podrobnega pregleda dejanske uporabe kmetijskih zemljišč in nelegalnih objektov na kmetijskih zemljiščih v občini. Pregledanih je bilo 869 ha kmetijskih zemljišč, ki jih 1354 zakupnikom daje v zakup Sklad kmetijskih zemljišč in gozdov Republike Slovenije. Pri tem pregledu je bilo ugotovljeno, da je 100 ha zemljišč neobdelanih, $29 \%$ zakupnikov pa ima na zemljišču postavljen objekt, ki ga je treba prijaviti gradbeni inšpekciji (Akcija ... 2013). Ta pregled stanja na terenu je vodil v spremembo Odloka o prostorskih ureditvenih pogojih za podeželje Občine Izola, v katerem so se podrobneje določila merila za postavitev pomožnih objektov na kmetijskih zemljiščih (Spremembe in dopolnitve ... 2014; slika 2).

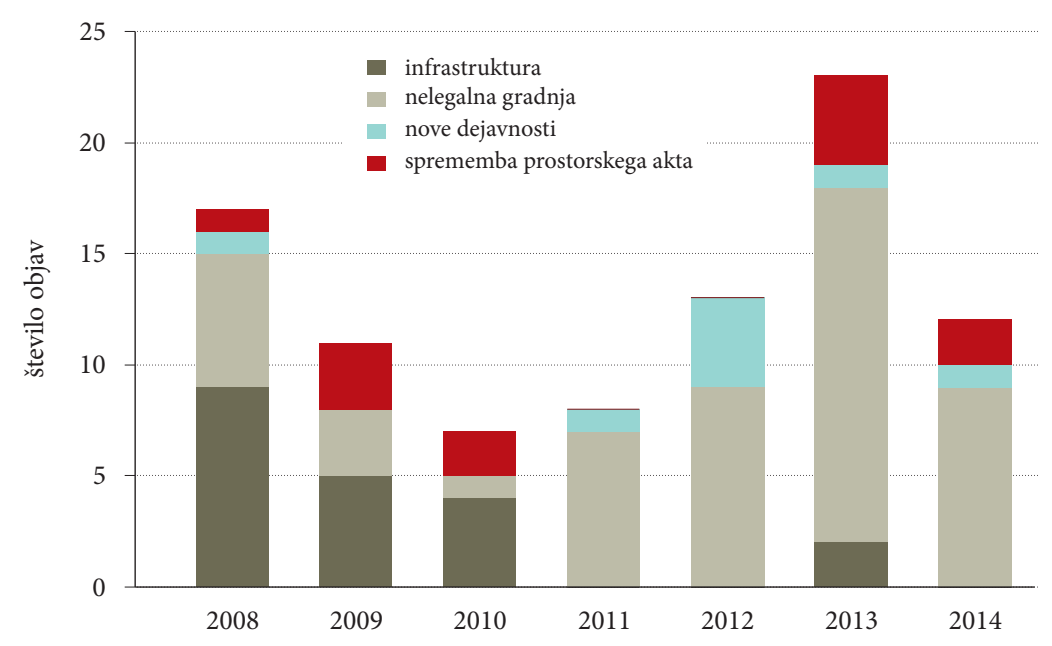

Slika 6: Najbolj trdoživi so konflikti zaradi nelegalnih gradenj, ki so se v obdobju 2008-2014 pojavljali vsako leto. 


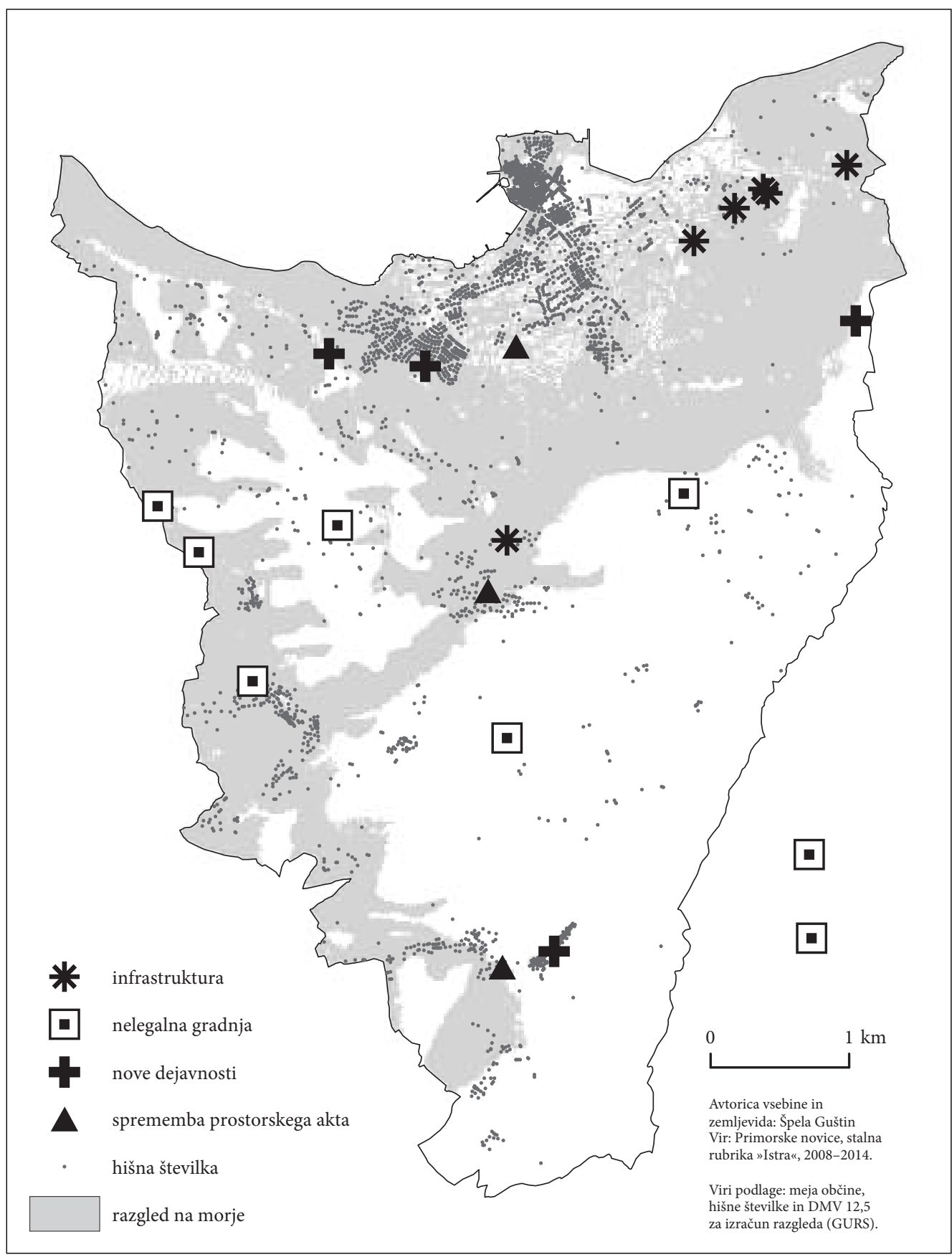

Slika 7: Konflikti zaradi gradnje infrastrukture, umeščanja novih dejavnosti in sprememb prostorskih aktov so večinoma $v$ ali $v$ bližini naselij, konflikti zaradi nelegalnih gradenj pa izven naselij na območjih, od koder je vidno morje. 
Konflikti zaradi gradnje infrastrukture se nanašajo predvsem na izgubo kmetijskih zemljišč, večina teh konfliktov pa je v bližini mesta (slika 7). Zaradi gradnje hitre ceste je v letih 2008-2010 in letu 2013 nastalo več konfliktov, povezanih z izgubo kmetijskih zemljišč (oznake 3, 8 in 10), rušenjem stanovanjskih stavb na trasi bodoče ceste (oznaki 19 in 20) in prevozom izkopanega materiala na deponijo v bližini Šareda (oznaka 18). Spremembam so nasprotovali večinoma okoliški kmetje, ki jim je cesta odvzela kmetijske površine, pri prevozih materiala na deponijo pa so bili nasprotniki prebivalci Šareda, ki so tudi uporabniki ceste na Šared. Glavni vzrok tega konflikta ni bila sama deponija, temveč vožnja težkih tovornjakov po cesti, ki je v slabšem stanju.

Trije konflikti so se pojavili zaradi sprememb prostorskega akta (oznake 1, 11 in 17). Konflikt 1 se je pojavil še preden je prišlo do uveljavitve novega prostorskega akta, razlog zanj je bilo nestrinjanje prebivalcev s predlagano gostoto pozidave v naselju. Konflikt 17 je nastal po sprejetju obvezne razlage odloka prostorskega akta, razlog pa je bila bojazen ob spremembi značilnega videza vasi zaradi možnosti gradnje večstanovanjskih stavb v strnjenem delu naselja. Konflikt 11 pa je nastal zaradi gradnje stanovanjske stavbe ob robu večjega vinograda, kar se je nekaj posameznikom zdelo sporno, saj so domnevali, da je stavba zgrajena nezakonito na območju kmetijskih zemljišč. Lokacija je dejansko nadomestna lokacija za stavbo, ki so jo porušili zaradi gradnje hitre ceste. Konflikti zaradi spremembe prostorskega akta so v vseh primerih ob oziroma v naseljih (slika 7).

Konfliktov zaradi umeščanja novih dejavnosti ni veliko (oznake 12, 4, 6 in 9). Pri konfliktu 12 so prebivalci nasprotovali postavitvi antene mobilnega operaterja. Konflikt 9 je sprožila ureditev pasjega poligona, konflikt 6 rušitev gostinskega objekta in kasneje nejasnost glede namenske rabe tega območja, konflikt 4 pa želja po ureditvi igrišča za golf na kmetijskih zemljiščih. Tudi ti konflikti so večinoma blizu naselja.

\section{3 Členitev podeželja ter vrsta in intenzivnost konfliktov po posameznih podeželskih območjih}

Podeželje v Občini Izola lahko glede na funkcijo ter vrsto in intenzivnost konfliktov členimo na tri območja: obmestje, podeželje z veliko doživljajsko zmožnostjo in podeželje s prevlado kmetijske dejavnosti (slika 8).

Mesto: Staro mestno jedro je zavarovano kot kulturni spomenik. Varuje se njegov značilen obris ter pogledi nanj z morja in s pobočij, ki ga na južni strani obkrožajo kot amfiteater. S konflikti na tem območju se $\mathrm{v}$ prispevku nismo podrobneje ukvarjali.

Obmestje: Južno od mesta, preko najboljših kmetijskih zemljišč, poteka obvoznica. Na tem območju je meja med mestom in podeželjem, ki jo določa prostorski plan občine. Med mestom in obvoznico so posamezna območja kmetijskih zemljišč, ki pa niso nujno del ureditvenega območja mesta. Pri nekaterih območjih je opazna velika nejasnost v prostorskih aktih. Območje po številki planske celote sodi v območje ureditvenega območja naselja, dejanska raba je kmetijska, začasno pa se ureja z določili, ki veljajo za podeželski del občine. Da prihaja do nejasnosti, kam območje dejansko sodi, je razvidno tudi iz nasprotujočih želja na zemljiščih - enkrat se obravnavajo kot kmetijska, drugič je tam želja po nekmetijskih dejavnostih. Ravninski obmestni del je poleg kmetijstva privlačen tudi za gradnjo infrastrukture. Zaradi tega prihaja do rušitev obstoječih stanovanjskih stavb, izgube kmetijskih zemljišč in nasprotovanja tamkajšnjih obdelovalcev kmetijskih zemljišč. Intenzivnost konfliktov je v tem obmestnem območju srednja, glavni razlog za konflikte pa širjenje pozidanih zemljišč in nejasnost meje med mestom in podeželjem ter s tem povezana različna mnenja glede umeščanja primernih dejavnosti na to območje.

Podeželje z veliko doživljajsko zmožnostjo: To območje je po površini največje. Obsega pobočja z obdelovalnimi terasami in slemena. Na obdelovalnih terasah so oljčniki, vinogradi in njive, na slemenih

Slika 8: Shematski prikaz razmestitve konfliktov na večfunkcijskem podeželju Občine Izola. Območja si sledijo z leve proti desni: mesto, obmestje, podeželje z veliko doživljajsko zmožnostjo, podeželje s prevlado kmetijske dejavnosti. 


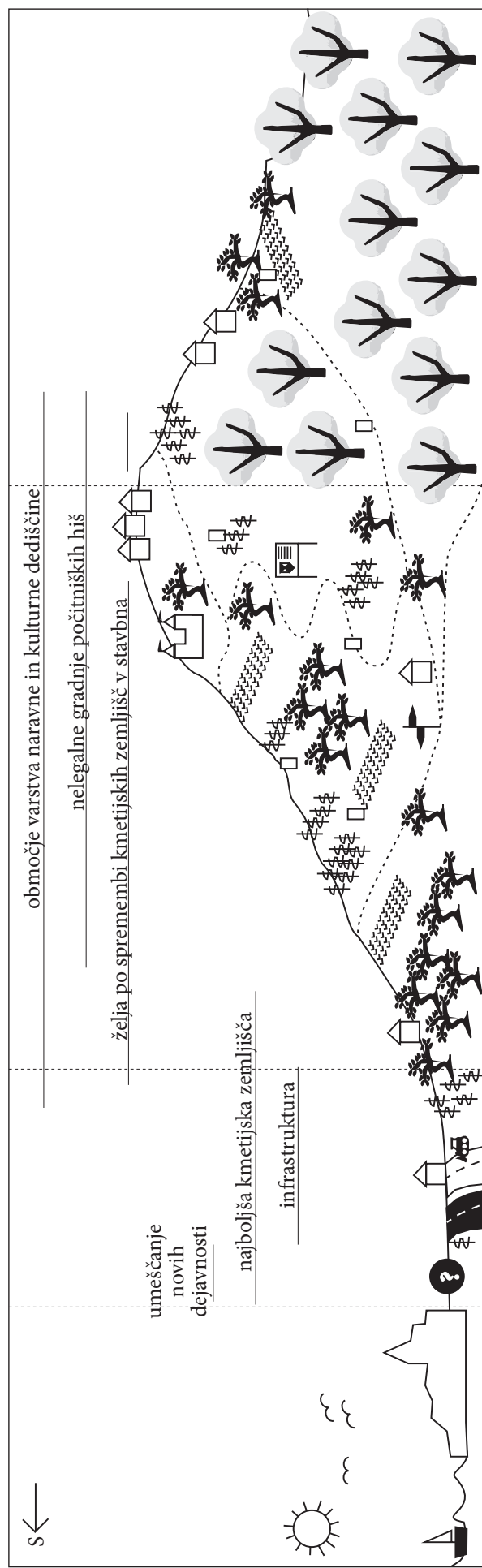

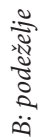

莺悉营
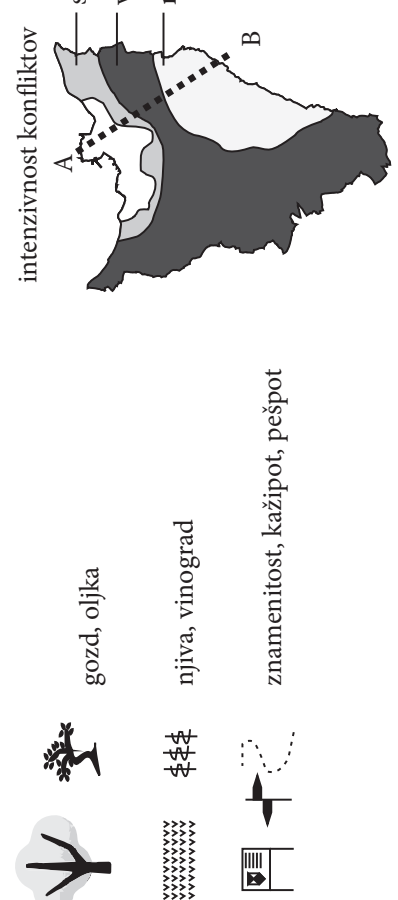

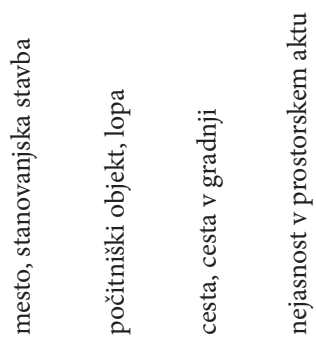

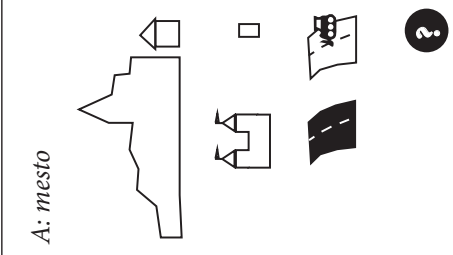


pa je zgoščena poselitev. Glavni dejavnik privlačnosti tega območja je razgled na morje in, v nekaterih delih, tudi na soline. Območje je zavarovano z različnimi režimi varstva naravne in kulturne dediščine, na državni ravni se del območja (»amfiteater «) varuje kot izjemna krajina, na severozahodu je del Krajinskega parka Strunjan, zavarovana so tudi stara vaška jedra naselij na slemenih. Znotraj tega območja so speljane kolesarske in peš poti, ki povezujejo mesto s podeželjem. Na izpostavljenih lokacijah z razgledom na morje in izven naselij se na kmetijskih zemljiščih pojavljajo nelegalne gradnje počitniških objektov, ki se po videzu običajno razlikujejo od drugih zgradb. Na kmetijskih zemljiščih je na tem območju prisoten tudi pojav uporabe lop, ki so namenjene spravilu kmetijskega orodja in pridelkov, ali $\mathrm{v}$ počitniške namene. Lope ne služijo prvotnemu namenu, ampak jih lastniki v toplejših mesecih pogosto uporabljajo kot počitniški objekt. Za območje je značilna velika intenzivnost konfliktov, ki so zelo raznovrstni. Glavni razlog zanje so nelegalne gradnje in nasprotovanje spremembam, ki bi spremenile individualne predstave prebivalcev o idiličnem podeželju oziroma značilen videz naselij (novogradnje, previsoke stavbe, pregosta pozidava, antene mobilnih operaterjev, igrišče za golf).

Podeželje s prevlado kmetijske dejavnosti: Podeželje, kjer ni območij varstva naravne ali kulturne dediščine, kjer ni razgleda na morje in ki je bolj oddaljeno od mesta, ima najmanjšo intenzivnost konfliktov. Prevladujeta kmetijska dejavnost in gozd. Glavni vzrok konfliktov, ki se pojavljajo na tem območju, so nelegalne gradnje lop za spravilo orodja na kmetijskih zemljiščih, v lasti Sklada kmetijskih zemljišč in gozdov.

\section{Sklep}

Slovensko podeželje se kot izrazito večfunkcijski prostor sooča s čedalje močnejšimi gospodarskimi, socialnimi, političnimi in okoljskimi pritiski na podeželske vire. Zaradi ohranjanja njihove raznovrstnosti in kakovosti je treba opredeliti podeželske vire kot podeželski kapital, v katerega lahko in iz katerega lahko izhajajo koristi. Ta pristop izhaja iz principov okoljske ekonomije, ki pravi, da je blagostanje človeštva dolgoročno odvisno od smotrne (uravnotežene) rabe raznovrstnega kapitala v krajšem obdobju. Podeželski kapital (opredelitev je povzeta po britanski Agenciji za podeželje) »je izdelek podeželja, njegovih vasi in trgov« (Garrod, Wornell in Youell 2006, 117-118). Čeprav se na prvi pogled zdi ta opredelitev preveč poenostavljena, pa je po drugi strani dragocena v tem, da opisuje podeželski kapital, ki vsebuje različne (ne)merljive elemente podeželja/podeželskosti. Ti so v prvi vrsti iz naravnega (na primer podeželska naselja, lokalne kulturne tradicije, divjad), pa tudi iz zgrajenega in socialnega kapitala. Podeželski kapital naj bi tako imel štiri funkcije (Garrod, Wornell in Youell 2006): (1) za kmete, predelovalce hrane in distributerje ustvarja tržno prednost ( $\mathrm{v}$ smislu prepoznavne in kakovostne blagovne znamke); (2) za podjetja, ki se ukvarjajo s trženjem dediščine, predstavlja pomembno kapitalsko osnovo; (3) posreduje ključne storitve na podeželju (lesna biomasa, viri za rekreacijo) in (4) privablja zunanja vlaganja. Kritično spoznanje je, da si pretekle, sedanje in prihodnje generacije delijo isto (podeželsko) premoženje, to je kapitalske zaloge, ki so temelj vsem gospodarskim dejavnostim. Kakovost življenja sedanje generacije je v mnogočem odvisna od tega, kako modro (uravnoteženo) so pretekle generacije upravljale te kapitalske zaloge. Blagostanje bodočih generacij je v veliki meri odvisno od njihove smiselne (uravnotežene) rabe s strani sedanje generacije, oziroma kako se bodo reševali stari in novi konflikti na podeželju.

Namen prispevka je bilo prepoznavanje, prikaz in analiza prostorske razporeditve ter spreminjanja števila in intenzivnosti konfliktov na podeželju Občine Izola v sedemletnem obdobju. Pregledali smo časopisne članke v stalni rubriki »Istra« v Primorskih novicah v letih 2008-2014 in evidentirali konflikte interesov, ki se pojavljajo na podeželju občine. V 87 člankih je bilo omenjenih 21 konfliktov, ki smo jih razdelili glede na trajanje, vzrok in predlagatelja spremembe. V občini prevladujejo enkratni konflikti, ki se nahajajo v bližini mesta. Najpogostejši vzrok konfliktov so nelegalne gradnje in gradnja infrastrukture, najpogostejši predlagatelj spremembe, ki povzroči konflikt, pa je investitor. Glede na funk- 
cijo območja ter vrsto in intenzivnost konfliktov lahko podeželje Občine Izola razdelimo na tri območja: obmestje, podeželje z veliko doživljajsko zmožnostjo in območje s prevlado kmetijske dejavnosti.

Število konfliktov ni vsako leto enako. Nekateri konflikti se pojavijo le enkrat, o drugih lahko beremo članke več let. Glede na trajanje smo konflikte razdelili na enkratne, ponavljajoče in večletne. Zato bi tudi opredelitev konflikta lahko dopolnili s časovno komponento: konflikt je enkratno, ponavljajoče se ali večletno nasprotje med akterji, ki nastane zaradi nezdružljivih interesov po omejeni dobrini. Pri štetju konfliktov pa je potrebna pazljivost, saj je možno, da njihovo število narašča le zaradi povečanega interesa časopisov (Wilkes in Ricard 2007).

Pozidave so pogost vir konfliktov, ker vključujejo zelo vidne spremembe v prostoru. Območja pozidave so zelo natančno opredeljena in predstavljajo jasen predmet, zoper katerega je mogoče izraziti nestrinjanje (Woods 2005, 212-214). Tudi rezultati, pridobljeni s pomočjo analize vsebine časopisnih člankov o konfliktih na podeželju Občine Izola, to potrjujejo.

Primer konfliktov zaradi pozidave je gradnja hitre ceste, ki je povzročila večje število enkratnih konfliktov in tudi vsi konflikti zaradi nelegalnih gradenj. V povezavi z gradnjo infrastrukture je tudi konflikt deponije na Šaredu, kamor se je vozilo izkopano gradivo iz predora Markovec (oznaka 18 na sliki 3e). Ta, v primerjavi z ostalimi, ni bil enkraten, temveč je trajal več let. Možen razlog za to je sočasna priprava prostorskega akta za naselje Šared, s katerim se niso strinjali prebivalci (oznaka 1) in ne le gradnja hitre ceste. Nezadovoljstvo s prostorskim aktom so izražali na najbližjem drugem objektu, ki mu je bilo mogoče nasprotovati. Možen krivec za nestrinjanje prebivalcev Šareda je bil tudi Odlok o začasnih ukrepih za zavarovanje urejanja prostora v Občini Izola (slika 2), ki je na Šaredu preprečeval novogradnje do sprejetja prostorskega akta. Nestrinjanje s spremembami prostorskih aktov ali večjimi gradnjami je le zavračanje spreminjanja prostora $\mathrm{v}$ prostor potrošnje (Mormont 1983, 570). Po prvotnih načrtih je bila bojazen prebivalcev prav ta: prihod novih prebivalcev iz notranjosti Slovenije, ki bi pozidali Šared s počitniškimi hišami. Eden od nasprotnikov je nezadovoljstvo povzel z besedami (Cerin 2013, 9): „Stanovanja bodo pokupili Ljubljančani, dva meseca na leto ne bomo mogli spati«. Naslov članka »Na podeželju želijo razvoj, a hkrati tudi mir« (Cerin 2013) nakazuje, da je konflikt povezan tudi s sindromom ne-na-mojem-dvorišču (NIMBY). Gradnja počitniških hiš pa ustvarja še več dvorišč in s tem še več nasprotnikov kakršnih koli novih dejavnosti (Farstad in Rye 2013). NIMBY je razlog tudi za konflikt, ki je nastal zaradi želje po postavitvi antene mobilnega operaterja. Antena sodi med objekte, ki jih ljudje na splošno sprejemamo ter dojemamo kot nujne in potrebne, a jih ne želimo na lastnem dvorišču (Dear 1992), kar je razvidno tudi iz naslova časopisnega članka o istovrstnem konfliktu iz sosednje Občine Piran (»Mobi imajo, antene pa ne bi? «; Hlaj 2010, 8).

Pretekle raziskave (Perpar 2002, 134 v: Perpar, Kovačič 2006, 67; Goluža 2014) so kot predmet spora omenjale hrup kmetijskih strojev in smrad zaradi kmetijske dejavnosti. Takih konfliktov na podeželju Občine Izola nismo zaznali.

Območja s pogledom na morje so pod velikim pritiskom zaradi pozidave in nelegalnih gradenj (Markandya in sodelavci 2008). Tudi na podeželju v Občini Izola je tako. Tretjina vseh konfliktov je povezana z nelegalnimi gradnjami. Prav ti konflikti so tudi med najintenzivnejšimi in se pojavljajo na najbolj privlačnih območjih, kjer se prekrivajo interesi različnih akterjev. Malo manj intenzivni so konflikti na obrobju mesta, ki se dojema kot začasen prostor ter kot "pokopališče podeželja in zibelka mesta« (Qviström 2007, 270).

Slabost uporabljene metode je $\mathrm{v}$ tem, da pristranskost časopisa lahko vpliva na število in izbor konfliktov (Barranco in Wisler 1999) ter na ne-poročanje o vsakem konfliktu (Earl in sodelavci 2004), saj se več poroča o dogodkih, ki se zgodijo bližje uredništvu časopisa (Barranco in Wisler 1999) ali so vanj vpleteni vplivnejši akterji. Uredništvo časopisa Primorske novice je v mestu (Kopru), zato je možno, da konfliktom na podeželju ne posveča enake pozornosti kot tistim v mestu in njegovi neposredni bližini. Iz analize štetja znakov in števila konfliktov glede na predlagatelja spremembe (slika 5) pa je razvidno, da se poročanje časopisov lahko razlikuje tudi glede na subjekt. Časnik Primorske novice je namreč namenjal več prostora konfliktom, kjer je spremembo in s tem konflikt povzročila Občina Izola. Podobne 
ugotovitve lahko zasledimo tudi pri preučevanju konfliktov v mestih (Janelle 1977). Pri poročanju o konfliktih je velikokrat težavno natančno razbrati, kdo je bil predlagatelj spremembe. Kot akter je naveden na primer investitor, a ni podrobneje opredeljen. Še posebno se take nejasne opredelitve pojavljajo pri gradnjah oziroma rušitvah nelegalnih stanovanjskih stavb.

Večina novic o Občini Izola je v časopisu objavljena v stalni rubriki »Istra«, zato menimo, da z izpustitvijo branja drugih delov časopisa (naslovnice, zadnje strani, rubrike »Aktualno« ter pisem bralcev) nismo izpustili nobenega konflikta. Konflikti, ki jim mediji posvečajo veliko pozornosti, so v časopisu običajno najprej napovedani na naslovnici, nato pa na naslednjih straneh sledi še članek. Če je tema še posebno aktualna, se o konfliktu lahko piše tudi trikrat: na naslovnici, v rubriki »Aktualno" in v rubriki »Istra «. Pri medijsko odmevnih konfliktih bi se z upoštevanjem objav iz drugih delov časopisa število znakov zelo povečalo. Ker nismo brali celotnega časopisa, je intenzivnost, ki smo jo merili s številom znakov, pri takih konfliktih manjša, kot je bila v resnici. Rezultati so pokazali, da v Občini Izola obstaja tudi območje, kjer je intenzivnost konfliktov zelo nizka. Zaradi uporabljene metode pa domnevamo, da se konflikti pojavljajo tudi tam, a zaradi oddaljenosti, tematike ali moči vpletenih akterjev niso dovolj zanimivi za medije.

Interese, ki skušajo razvoj usmeriti vsak v svojo smer, je treba usklajevati. Poznavanje različnih interesov in konfliktov, ki nastajajo med njimi, pomaga pri odločanju o prihodnjem razvoju. V prihodnje lahko pričakujemo nadaljevanje že poznanih konfliktov, na primer ob začetku gradnje načrtovanih prometnic (ceste Jagodje-Šared in Jagodje-Lucija), ob vsakem večjem posegu na kmetijskih zemljiščih in pri večini sprememb, ki jih bo predlagala Občina Izola, ne glede na vrsto spremembe. Pričakujemo pa lahko tudi pojav novih, do sedaj še nepoznanih konfliktov. Naša predpostavka temelji na dejstvu, da se v tem izjemno privlačnem podeželskem prostoru pojavlja čedalje več socialnih skupin z zelo individualiziranimi pogledi glede rabe virov oziroma podeželskega kapitala. Posledično pričakujemo tudi večjo odzivnost socialnih skupin na pričakovane spremembe prostorskih dokumentov, za katere pa ne vemo, kako intenzivno bodo zaznamovane $\mathrm{v}$ časopisju in drugih medijih. Za podrobnejšo sliko konfliktov bi bilo morda v prihodnje smiselno spremljati pojavnost in odzive na konflikte tudi v spletnih medijih.

\section{Viri in literatura}

Akcija pregleda dejanske uporabe kmetijskih zemljišč in nelegalnih objektov na območju občine Izola. Ministrstvo za kmetijstvo in okolje. Ljubljana, 2013. Medmrežje: http://www.mko.gov.si/nc/si/ medijsko_sredisce/novica/article/1328/6562/ (24.6.2013).

Barbič, A. 2005: Izzivi in priložnosti podeželja. Ljubljana.

Barranco, J., Wisler, D. 1999: Validity and systematicity of newspaper data in event analysis. European Sociological Review 15-3. Oxford.

Bennett, G., Davies, P. J. 2015: Urban cemetery planning and the conflicting role of local and regional interests. Land Use Policy 42. Guildford. DOI: http://dx.doi.org/10.1016/j.landusepol.2014.08.011

Boulding, K. 1962: Conflict and Defense: A General Theory. New York.

Bowen, R. L., Cox, L. J., Fox, M. 1991: The interface between tourism and agriculture. The Journal of Tourism Studies 2-2. Townsville.

Bučar Ručman, A. 2011: Medijsko poročanje o kriminaliteti v Sloveniji. Revija za kriminalistiko in kriminologijo 62-1. Ljubljana.

Bufon, M. 2007: Osnove politične geografije. Koper.

Cerin, M. 2013: Na podeželju želijo razvoj, a hkrati tudi mir. Primorske novice 67-288 (13. 12.2013).

Cimprič, T., Lisec, A., Zavodnik Lamovšek, A. 2013: Analiza višine plačila za spremembo namembnosti kmetijskih zemljišč v Sloveniji po letu 1979. Geodetski vestnik 57-3. Ljubljana.

Clendenning, G., Field, D. R. 2005: Seasonal residents: members of community or part of the scenery? Amenities and Rural Development. Cheltenham. 
Coser, L. 1964: The functions of social conflict. An Examination of the Concept of Social Conflict and its Use in Empirical Sociological Research. New York.

Dahrendorf, R. 1959: Class and Class Conflict in Industrial Society. Stanford.

Darly, S., Torre, A. 2013: Conflicts over farmland uses and the dynamics of "agri-urban « localities in the Greater Paris Region: An empirical analysis based on daily regional press and field interviews. Land Use Policy 33. Guildford. DOI: http://dx.doi.org/10.1016/j.landusepol.2012.12.014

Daugstad, K., Rønningen, K., Skar, B. 2006: Agriculture as an upholder of cultural heritage? Conceptualizations and value judgements - A Norwegian perspective in international context. Journal of Rural Studies 22-1. Oxford. DOI: http://dx.doi.org/10.1016/j.jrurstud.2005.06.002

Dear, M. 1992: Understanding and overcoming the NIMBY syndrome. Journal of the American Planning Association 58-3. Washington. DOI: http://dx.doi.org/10.1080/01944369208975808

Dixon, J., Sherman, P. 1991: Economics of protected areas. Ambio 20-2. Stockholm.

Earl, J., Martin, A., McCarthy, J. D., Soule, S. A. 2004: The use of newspaper data in the study of collective action. Annual Review of Sociology 30-1. Palo Alto. DOI: http://dx.doi.org/10.1146/ annurev.soc.30.012703.110603

Erjavec, K., Poler Kovačič, M. 2011: Novinarsko sporočanje o poskusnem izračunu vrednosti nepremičnin v Sloveniji. Geodetski vestnik 55-3. Ljubljana.

European Heritage Heads Forum, 2010. Izjava o izzivih in tveganjih dediščine in turizma. Medmrežje: http://www.zvkds.si/sl/zvkds/varstvo-kulturne-dediscine/ izjave-sporazumi-deklaracije/ (1.3.2015).

Farstad, M., Rye, J. F. 2013: Second home owners, locals and their perspectives on rural development. Journal of Rural Studies 30. Oxford. DOI: http://dx.doi.org/10.1016/j.jrurstud.2012.11.007

Garrod, B., Wornell, R., Youell, R. 2006: Re-conceptualising rural resources as countryside capital: The case of rural tourism. Journal of Rural Studies 22-1. Oxford. DOI: http://dx.doi.org/10.1016/ j.jrurstud.2005.08.001

Golobič, M., Marušič, J., Kovačič, M. 2003: Možnosti za usklajevanje razvoja kmetijstva z drugimi družbenimi interesi na slovenskem podeželju, primer občine Komenda. Zbornik Biotehniške fakultete Univerze v Ljubljani, Kmetijstvo 81-2. Ljubljana.

Goluža, M. 2014: Vloga počitniških bivališč na podeželju: primerjava med občinama Cerklje na Gorenjskem in Komen. Geografski vestnik 85-1. Ljubljana. DOI: http://dx.doi.org/10.3986/GV86204

Gosar, M., Kocjančič, L., Marušič, M., Rudolf, F., Medija, F., Lenardič, A., Vatovec, S., Rebernik, Z., Bombač, A. 1976: Kmetijski prostorski načrt za obalno območje - 1976. Skupščina obalne skupnosti, Oddelek za načrtovanje, statistiko in cene. Koper.

Grimble, R., Wellard, K. 1997: Stakeholder methodologies in natural resource management: A review of principles, contexts, experiences and opportunities. Agricultural Systems 55-2. New York. DOI: http://dx.doi.org/10.1016/s0308-521x(97)00006-1

Haukeland, J. V., Daugstad, K., Vistad, O. I. 2011: Harmony or conflict? A focus group study on traditional use and tourism development in and around Rondane and Jotunheimen National Parks in Norway. Scandinavian Journal of Hospitality and Tourism 11, Supplement 1. Oslo. DOI: http://dx.doi.org/10.1080/15022250.2011.632597

Henderson, S. R. 2005: Managing land-use conflict around urban centres: Australian poultry farmer attitudes towards relocation. Applied Geography 25-2. New York. DOI: http://dx.doi.org/10.1016/ j.apgeog.2005.03.001

Hlaj, N. 2010: Mobi imajo, antene pa ne bi? Primorske novice 64-1 (4.1.2010).

Janelle, D. G. 1977: Structural dimensions in the geography of locational conflicts. Canadian Geographer/Le Géographe canadien 21-4. Toronto. DOI: http://dx.doi.org/10.1111/j.1541-0064.1977.tb01004.x

Janelle, D. G., Millward, H. A. 1976: Locational conflict patterns and urban ecological structure. Tijdschrift voor economische en sociale geografie 67-2. Amsterdam. DOI: http://dx.doi.org/ 10.1111/j.1467-9663.1976.tb01391.x

Janelle, D. G. 1979: Correlates of locational conflict. Canadian Journal of Regional Science 2-2. Halifax. 
Jeršič, M. 1986: Sekundarna počitniška bivališča v Sloveniji in Zahodni Istri. Geografski vestnik 40. Ljubljana.

Jones, C., Baker, M., Carter, J., Jay, S., Short, M., Wood, C. 2005: Introduction. Strategic Environmental Assesment and Land Use Planning: An International Evaluation. London.

Klemenčič, M. M., Lampič, B., Potočnik Slavič, I. 2008: Življenjska (ne)moč obrobnih podeželskih območij v Sloveniji. GeograFF 3. Ljubljana.

Kodeks slovenskih novinarjev, 2015. Medmrežje: http://www.razsodisce.org/razsodisce/kodeks_ns.html (4. 4. 2015).

Lampič, B. 2008: Kmetijstvo v Mestni občini Ljubljana: relikt ali razvojni potencial. GeograFF 2. Ljubljana.

Lampič, B., Mrak, I. 2008: Vrednote, vrednosti in razvojni potenciali območij varovanja. Dela 29. Ljubljana. DOI: http://dx.doi.org/10.4312/dela.29.11.145-159

Mann, C., Jeanneaux, P. 2009: Two approaches for understanding land-use conflict to improve rural planning and management. Journal of Rural and Community Development 4-1. Brandon.

Markandya, A., Arnold, S., Cassinelli, M., Taylor, T. 2008: Protecting coastal zones in the Mediterranean: An economic and regulatory analysis. Journal of Coastal Conservation 12-3. Dordrecht. DOI: http://dx.doi.org/10.1007/s11852-008-0038-3

Mlakar, A. 2009: Negotovost v prostorskonačrtovalnih postopkih. Urbani izziv 20-2. Ljubljana. DOI: http://dx.doi.org/10.5379/urbani-izziv-2009-20-02-003

Mormont, M. 1983: The emergence of rural struggles and their ideological effects. International Journal of Urban and Regional Research 7-4. Oxford. DOI: http://dx.doi.org/10.1111/j.1468-2427.1983.tb00406.x

Neuendorf, K. A. 2002: The Content Analysis Guidebook. London.

Pavón, D., Ventura, M., Ribas, A., Serra, P., Saurí, D., Breton, F. 2003: Land use change and socio-environmental conflict in the Alt Empordà county (Catalonia, Spain). Journal of Arid Environments 54-3. Amsterdam. DOI: http://dx.doi.org/10.1006/jare.2002.1077

Pelletier, M., Joerin, F., Kestens, Y., Villeneuve, P. 2011: Conflict activity in the neighborhoods of Quebec City (Canada), 1989-2000. Applied Spatial Analysis and Policy 4-3. Dordrecht. DOI: http://dx.doi.org/ 10.1007/s12061-010-9050-8

Perpar, A., Kovačič, M. 2006: Prostorski vidiki razvoja kmetij. Dela 25. Ljubljana. DOI: http://dx.doi.org/ 10.4312/dela.25.5.61-71

Perpar, A. 2002: Razvojne značilnosti slovenskega podeželja. Magistrsko delo, Oddelek za agronomijo Biotehniške fakultete. Ljubljana.

Potočnik Slavič, I. 2010: Endogeni razvojni potenciali slovenskega podeželja. GeograFF 7. Ljubljana.

Power, T. M. 2005: The supply and demand for natural amenities: an overview of theory and concepts. Amenities and Rural Development. Cheltenham.

Program razvoja podeželja 2014-2020. Ministrstvo za kmetijstvo in okolje. Ljubljana. Medmrežje: http://www.program-podezelja.si/sl/22-vsebina-prp-2014-2020 (29.5.2015).

Qviström, M. 2007: Landscapes out of order: Studying the inner urban fringe beyond the rural - urban divide. Geografiska Annaler: Series B, Human Geography 89-3. Stockholm. DOI: http://dx.doi.org/ 10.1111/j.1468-0467.2007.00253.x

Shackelford, G. E., Steward, P. R., German, R. N., Sait, S. M., Benton, T. G. 2015: Conservation planning in agricultural landscapes: hotspots of conflict between agriculture and nature. Diversity and Distributions 21-3. Oxford. DOI: http://dx.doi.org/10.1111/ddi.12291

Simoneti, M., Vertelj Nared, P. 2011: Varstvo kot razvojna priložnost ob upoštevanju kompleksnosti. Razvoj zavarovanih območij v Sloveniji. Ljubljana.

Spremembe in dopolnitve Odloka o prostorskih ureditvenih pogojih za podeželje občine Izola, povzetek za javnost. Medmrežje: http://izola.si/wp-content/uploads/2014/04/ Povzetek-za-javnost-slo.pdf (24. 4. 2014).

Slovar Slovenskega knjižnega jezika. Ljubljana, 2014. Medmrežje: http://www.fran.si/130/sskj-slovarslovenskega-knjiznega-jezika (17.1.2015). 
Stanič, I., Jakoš, A., Pavliha, M., Ploštajner, Z. 2000: Bivalne navade Slovencev in njihov vpliv na prostor - občasna bivališča. Elaborat, Urbanistični inštitut Republike Slovenije. Ljubljana. Medmrežje: http://www.arhiv.mop.gov.si/fileadmin/mop.gov.si/pageuploads/podrocja/prostor/pdf/ prostor_slo2020/2_6_dokument.pdf(13.3.2015).

The Dictionary of Human Geography. Oxford, 2009.

The Future of Rural Society. Office for official pubblications of the european communities. Luksemburg, 1988.

Vanslembrouck, I., van Huylenbroeck, G. 2005: Landscape Amenities: Economic Assessment of Agricultural Landscapes. Landscape Series 2. Dordrecht. DOI: http://dx.doi.org/10.1007/1-4020-3172-6_4

von der Dunk, A., Grêt-Regamey, A., Dalang, T., Hersperger, A. M. 2011: Defining a typology of peri-urban land-use conflicts: A case study from Switzerland. Landscape and Urban Planning 101-2. Amsterdam. DOI: http://dx.doi.org/10.1016/j.landurbplan.2011.02.007

Vrščaj, B. 2011: Sprememba rabe zemljišč in kmetijstvo. Kazalci okolja v Sloveniji. Agencija Republike Slovenije za okolje. Ljubljana. Medmrežje: http://kazalci.arso.gov.si/?data=indicator\&ind_id=460 (21.4.2015).

Wehrmann, B. 2008: Land Conflicts: A Practical Guide to Dealing with Land Disputes. Eschborn. Medmrežje: http://commdev.org/userfiles/08_GTZ_land_conflicts.pdf (14.10.2014).

Wilkes, R., Ricard, D. 2007: How does newspaper coverage of collective action vary?: Protest by indigenous people in Canada. The Social Science Journal 44-2. New York. DOI: http://dx.doi.org/ 10.1016/j.soscij.2007.03.017

Woods, M. 1998: Researching rural conflicts: hunting, local politics and actor-networks. Journal of Rural Studies 14-3. Oxford. DOI: http://dx.doi.org/10.1016/S0743-0167(97)00038-7

Woods, M. 2003a: Deconstructing rural protest: the emergence of a new social movement. Journal of Rural Studies 19-3. Oxford DOI: http://dx.doi.org/10.1016/S0743-0167(03)00008-1

Woods, M. 2003b: Conflicting environmental visions of the rural: Windfarm development in Mid Wales. Sociologia Ruralis 43-3. Oxford. DOI: http://dx.doi.org/10.1111/1467-9523.00245

Woods, M. 2005: Rural Geography: Processes, Responses and Experiences in Rural Restructuring. London. Woods, M. 2006: Redefining he 'rural question': The new 'politics of the rural' and social policy. Social Policy and Administration 40-6. Oxford. DOI: http://dx.doi.org/10.1111/j.1467-9515.2006.00521.x Zakon o kmetijskih zemljiščih. Uradni list Republike Slovenije 71/2011, 58/2012. Ljubljana.

Zakon o prostorskem načrtovanju. Uradni list Republike Slovenije 33/2007, 70/2008, 108/2009, 80/2010, 43/2011, 57/2012, 109/2012, 76/2014, 14/2015. Ljubljana.

\section{Summary: Identification and spatial distribution of conflicts in rural areas}

(translated by the authors)

Contemporary Slovenian rural areas are subjected to several issues; amongst them the conflicts of interest are evident and important. Woods (2005) divided conflicts in the rural areas into three groups: the conflict between the need for rural development and environmental impact, conflict between agricultural and conservation interests with regard to the use of natural resources, and the conflict between the rural lifestyle and restricting the hunting of wild animals. Attractive and multifunctional Slovenian rural areas often perform as a junction of various stakeholders (farmers, entrepreneurs, second home owners, environmentalists, tourists, local authorities, investors, etc.) and their interests. Interrelations among interests of social groups and their diverse requests or expectations towards the use of rural resources very often lead into conflict.

In Slovenia, there is no official record or database on conflicts in rural areas as well as no common definition of conflict. Within the framework of this paper a "conflict« is defined as "a unique, recurrent or multiannual contradiction between the stakeholders caused by irreconcilable interests over the 
limited resource . The paper focuses on identification and spatial distribution of conflicts in rural areas of the Municipality of Izola (south-western part of Slovenia), their spatial dimension and cause-effect connection. In the studied rural localities, the farmers are important stakeholders; relevant are also holiday homes owners, nature and cultural heritage protectors, and local authorities. The data was obtained by analysing the contents of regional journal »Primorske novice«, issued all week, excluding Sundays and holidays, during the period 2008-2014. Newspaper content analysis is a quantitative method for summarizing and analysing the messages (Neuendorf 2002). By counting the occurrence of predefined variables (words) in the messages we obtain numerical summary of the revised text messages (Neuendorf 2002), which can identify the patterns of occurrence of various events in time (Barranco and Wisler 1999). The method is widely used in the study of conflict (e.g. Janelle and Millward 1976; Janelle 1977; 1979; von der Dunk et al. 2011; Darly and Torre 2013; Pelletier et al. 2011).

We searched for articles with the following topics: (a) conflicts of interest in the rural areas of the surveyed municipality, (b) situations where there was obvious disagreement between two or more stakeholders and (c) articles that had defined location (point, line or area) or we were able to locate the site with the help of photos. In the rubric "Istra « of the mentioned newspaper we encountered 87 articles on the conflict in rural areas of the Municipality of Izola, with indicated 21 conflicts. Conflicts are distinguished by location, intensity (number of posts and the number of characters without spaces), the initiator of change (an investor, a farmer, municipality, DARS - Motorway Company in the Republic of Slovenia, more proposers), the reason for the formation of conflict (illegal construction, infrastructure construction, planning the placement of new activities / object, change of the spatial planning act) and duration (single, multi-annual, recurring).

Where the areas of different interests overlap, there is a conflict, but also a mutual benefit. Since the conflicts are tied to location we tried to make a zonation (depending on the function of the area and type and intensity of conflicts) of rural areas in the surveyed municipality (Figure 8; the old town as protected cultural monument is not discussed in this paper).

(1) Suburban zone is located south of the town; a newer bypass is located on the best agricultural land. This zone experiences the boundary between urban and rural areas, defined by the municipality spatial plan, and there is a significant lack of clarity in the mentioned documents. Interest of mixed land use occur, new conflicts arise. The intensity of conflicts in the suburban zone is evaluated as medium.

(2) Attractive rural zone covers the major part of Izola municipality. It includes cultivated terraces on the sunny slopes (of olive groves, vineyards and fields), on the ridges it is densely populated. The main pull factor here is the sea view, in some parts even on the salt pans. The area is protected with different regimes (natural and cultural heritage) at the national level (»amphitheatre «), in the north-western part there is a small part of the Regional Park Strunjan (salt pans), protected are also the old village cores on the ridges. Several tourist infrastructure elements (agritourism, thematic routes, etc.) are to be found here as well. In exposed locations (sea view) and outside the settlements we can identify illegal constructions of holiday homes (various forms). They mostly reside on agricultural land and usually differ in appearance from other buildings. This zone is characterized by high intensity of conflicts.

(3) Rural zone with predominant agriculture and mostly covered by forest, is out of the reach of sea view, has no protected areas and the lowest intensity of conflict.

Reconciliation of different interests is the task of spatial planning. Rural areas have large reserves of rural capital (landscape, flora and fauna, biodiversity, rural settlements, routes, geology, air and water quality, forests, local customs, cuisine, events and language; Garrod et al. 2006), which are the basis for the development of tourism and help to maintain the protected areas. The interests of all stakeholders should be coordinated as their sectoral treatment leads to new and more complex conflicts (Golobič et al. 2003). This is the task of spatial planning (Zakon o prostorskem ... 2007, Article 3), the duty of the representatives of all interests in the area, however, that their interests are aligned so that the subsequent use of the spatial planning document does not cast doubt (Mlakar 2009). 
Geographical identification of stakeholders and social groups, knowledge on their different interests and conflicts which arise between them, might help with the future decision-making processes. In the future we can expect a continuation of the already known conflicts, for example, at the beginning of the construction of the planned roads (roads Jagodje-Šared and Jagodje-Lucija), at every major intervention on agricultural land, etc. We can also expect the emergence of new, hitherto unknown conflicts. Our assumption is based on the fact that in these extremely attractive rural areas with heterogeneous stakeholders and social groups we might expect highly personalized views on usage of the rural capital. As a result, we expect even greater responsiveness of social groups on the expected changes in planning documents for which we do not know how intense will be marked in the press and other media. For a more detailed monitoring of future (potential) conflict hotspots and mechanism it is reasonable to monitor the incidence of and responses to the conflicts in the online media as well. 
